\title{
Probiotic Candidates among Dairy Lactobacilli and Streptococcus Thermophiles Strains for Control of the Oral Pathogen Porphyromonas Gingivalis
}

\author{
Michaela Michaylova ${ }^{1}$, Tsvetelina Yungareva ${ }^{1}$, Zoltan Urshev ${ }^{1}$, Yana Dermendzieva ${ }^{2}$, \\ Blagovesta Yaneva ${ }^{2}$, Iliyan Dobrev ${ }^{3}$ \\ ${ }^{1}$ LB Bulgaricum PLC, R\&D Center, Sofia, Bulgaria \\ ${ }^{2}$ Department of Periodontology and Oral Mucosa Diseases, Faculty of Dental Medicine, Medical University of Plovdiv, Plovdiv, Bulgaria \\ ${ }^{3}$ Department of Microbiology, University of Food Technology, Plovdiv, Bulgaria \\ Corresponding author: Michaela Michaylova, LB Bulgaricum PLC, R\&D Center, 9 Saborna St., 1000 Sofia, Bulgaria; E-mail: \\ michaylova.m@lbbulgaricum.bg
}

Received: 15 July 2020 Accepted: 21 Oct $2020 \diamond$ Published: 31 Oct 2021

Citation: Michaylova M, Yungareva T, Urshev Z, Dermendzieva Y, Yaneva B, Dobrev I. Probiotic candidates among dairy Lactobacilli and Streptococcus thermophiles strains for control of the oral pathogen Porphyromonas gingivalis. Folia Med (Plovdiv) 2021;63(5):720-5. doi: 10.3897/folmed.63.e56551.

\begin{abstract}
Introduction: The gram-negative bacterium Porphyromonas gingivalis is a major causative agent of periodontitis in adults. It is also associated with disorders of the cardiovascular and endocrine systems, rheumatoid arthritis, pancreatic cancer, and Alzheimer's disease. Lactic acid bacteria (LAB) present in the oral cavity or introduced as probiotic preparations can support successful treatment of periodontitis due to their antagonism with the pathogen.
\end{abstract}

Aim: The aim of this study was in vitro assessment of the antimicrobial activity of Lactobacillus spp. and Streptococcus thermophilus against $P$. gingivalis.

Materials and methods: The antimicrobial effect of lactobacilli or $S$. thermophilus from the LBB Culture collection against $P$. gingivalis DSM 20709 was evaluated with the well diffusion assay on Wilkins Chalgren blood agar. Inhibition of the pathogen was evaluated by measuring the diameter of clear zones around the wells.

Results: Application of milk fermented with selected LAB resulted in a bacteriostatic effect. The most active culture was $S$. thermophilus 187/4, followed by L. delbr. ssp. bulgaricus (LBB.B1054, C3/2 and LBB.B120), L. helveticus LBB.H48/1 and L. rhamnosus I-1/13. The respective reconstituted freeze-dried preparations had a stronger inhibitory effect on the pathogen with the formation of clear bactericidal zones. The effect of milk acidified with lactic acid was apparent with minimal bactericidal zone observed at concentration of $0.1 \%$. The effectiveness of the assay was confirmed with Elgydium and Eludril.

Conclusions: P. gingivalis DSM 20709 was sensitive to the metabolites produced in fermented milk by selected strains of $L$. delbr. ssp. bulgaricus, L. helveticus, L. rhamnosus, and S. thermophilus. Reconstituted freeze dried fermented milk had a stronger inhibitory effect compared to fresh samples. Lactic acid produced by lactic acid bacteria was the key component for inhibition of the pathogen.

\section{Keywords}

inhibition, Lactobacillus, periodontitis, Streptococcus thermophilus 


\section{INTRODUCTION}

Following caries, periodontitis is the second, most frequent chronic inflammatory disease of the oral cavity. It is initiated as inflammation of the gingiva followed by tooth loss and bone destruction. Periodontal disease has not only stomatological consequences, but it can also affect the cardio-vascular system, the endocrine system, the joints, etc. One of the causative agents of chronic periodontitis in adults is Porphyromonas gingivalis. Its major virulent factors are lipopolysaccharides (LPS), capsular polysaccharide (CPS), fimbriae responsible for adherence to salivary proteins attachment and a group of cell surface cysteine proteinases - gingipains. ${ }^{1}$ Also, this pathogen has the capability of biofilm formation, which makes it one of the main members of the core "red complex" consortium in periodontitis ${ }^{2}$, along with Treponema denticola and Tannerella forsythia. Presently, extensive data of case-controlled studies have been accumulated proving a statistically significant relationship between the presence of $P$. gingivalis and periodontal diseases. ${ }^{3}$ Furthermore, Sato et al. ${ }^{4}$ showed that $P$. gingivalis is responsible for the aggravation of collagen-induced arthritis mainly due to the synthesis of peptidyl arginine deiminase that produces rheumatoid arthritis-related auto-antigens. Their results from experiments with mice demonstrated that $P$. gingivalis was a mediator between periodontitis and rheumatoid arthritis through its activity on the intestinal immune system and microflora. In a review by Öğrendik ${ }^{5}$, pancreatic cancer is determined as the fourth leading cause of cancer-related mortality worldwide and that oral pathogens are linked to the etiology of the disease. Singhrao et al. ${ }^{6}$ discuss the potential link between $P$. gingivalis periodontal infection and Alzheimer's disease.

Periodontitis therapy involves local cleaning and smoothing of dental root surfaces, application of oral hygiene preparations and frequently - systemic antibiotic therapy. Recently, great interest has been focused on the application of probiotic bacteria and their effect on oral pathogens. Numerous studies have shown that the consumption of fermented milk products, lactic acid bacteria probiotic preparations and lactobacilli in particular can serve as auxiliary tools in the successful treatment of periodontitis. ${ }^{7-11}$ Most importantly, in vitro studies are followed by randomized confirmatory control trials. Matsubara et al. ${ }^{12}$ have reviewed 12 such trials up to March, 2016 and have reached the conclusion that oral administration of probiotics is safe and effective treatment to accompany antibiotic therapy.

\section{AIM}

The aim of this study was in vitro assessment of the antimicrobial activity of Lactobacillus spp. and S. thermophilus against $P$. gingivalis.

\section{MATERIALS AND METHODS}

\section{Bacterial strains and culture conditions}

The antimicrobial effect of lactic acid bacteria was evaluated against $P$. gingivalis DSM 20709 as a test culture. Lactobacilli and $S$. thermophilus were derived from the LBB Culture collection (LB Bulgaricum Plc., Sofia, Bulgaria) with the exception of L. rhamnosus NBIMCC 507 (National Bank for Industrial Microorganisms and Cell Cultures - Bulgaria) and $L$. reuteri which was isolated from a commercial probiotic oral food supplement (Table 1). P. gingivalis was propagated in Wilkins Chalgren broth (CONDA) under anaerobic conditions at $37^{\circ} \mathrm{C}$ for up to 72 hours. Enumeration of the viable cells of the pathogen and the well-diffusion assay were performed on Wilkins Chalgren blood agar (Wilkins Chalgren agar supplemented with 5.0\% defibrinated sheep blood). Dairy lactobacilli and S. thermophilus were grown in sterile $10.0 \%$ reconstituted skim milk powder for 16 hours at $37^{\circ} \mathrm{C}$ and used either fresh or followed by freeze-drying. Thermal inactivation of L. delbr. ssp. bulgaricus LBB.B1054 prior to lyophilisation was carried out for 1 hour at $63^{\circ} \mathrm{C}$.

\section{Agar well diffusion assay}

The agar well diffusion assay was performed as described by Soleimani et al. ${ }^{13}$ with minor modifications. Mid log-phase culture of $P$. gingivalis $\left(10^{5}-10^{6} \mathrm{cfu} / \mathrm{ml}\right)$ was spread on the surface of Wilkins Chalgren blood agar. Wells $(6.0 \mathrm{~mm})$ were punched in the agar and filled with $50 \mu \mathrm{l}$ of 1 . fermented milk sample; 2 . reconstituted (with distilled water to $10.0 \%$ dry matter) freeze-dried fermented milk; 3 . non-inoculated milk (negative control); 4. milk, acidified with lactic acid (0.1-7.0\% final concentration) or 5. one of the commercial preparations Eludril Classic antiplaque mouth rinse or ELGYDIUM ANTI-PLAQUE toothpaste (both products of Pierre Fabre ORAL CARE, France) as positive controls. The inoculated plates were incubated anaerobically at $37^{\circ} \mathrm{C}$ for $4-5$ days. The inhibition of the pathogen was evaluated by measuring the diameter of clear zones $(\mathrm{mm})$ around the wells in which no growth (bactericidal effect) or supressed growth (bacteriostatic effect) of $P$. gingivalis DSM 20709 was observed. Average values for four parallel wells were recorded.

\section{RESULTS}

In the agar well diffusion assay, fermented milk or reconstituted freeze-dried fermented milk containing viable LAB was introduced into the wells. Therefore, a limited zone of $\mathrm{LAB}$ growth around the wells was observed for some strains, followed either by a clear zone of bactericidal effect against the pathogen or a zone of bacteriostatic effect with partially inhibited growth of $P$. gingivalis. The application of milk 
fermented with the selected LAB resulted in strain-specific bacteriostatic effect observed around the wells (Table 1). The most active culture was $S$. thermophilus $187 / 4$, followed by three strains of $L$. delbr. ssp. bulgaricus (B1054, C3/2 and B120), L. helveticus LBB.H48/1, and L. rhamnosus I-1/13. The inhibitory effect of these strains was comparable to the L. reuteri strain isolated from a commercial probiotic preparation. Another eight strains had no visible effect on $P$. gingivalis. For some of the strains, like L. rhamnosus I-4/1 and L. rhamnosus NBIMCC 507, the correct assessment of the inhibitory effect was difficult due to the growth of the LAB around the well.

Although freeze-dried fermented milk preparations were reconstituted with water to obtain the same dry weight as before lyophilisation, when introduced into the wells, a stronger inhibitory effect on the pathogen was observed compared to initial fermented milks with the formation of clear bactericidal zones (Table 1). In the case of L. delbr. ssp. bulgaricus LBB.B1054 a valid assessment of the inhibitory effect of the freeze-dried preparation was only possible after heat inactivation of the culture prior to lyophilisation to eliminate the growth of LAB around the well.

As with fermented milks, the reconstituted freeze-dried preparation of $S$. thermophilus $187 / 4$ showed the strongest inhibition of the pathogen among all tested preparations (Fig. 1). An inhibitory effect was also confirmed for freeze-dried preparations of $L$. delbr. ssp. bulgaricus LBB. B1054 and C3/2, L. helveticus LBB.H48/1 and L. rhamnosus I-1/13, again to a much bigger extent than observed for initial fermented milks. For strains L. delbr. ssp. lactis LBB. L1266, L. rhamnosus I-4/1, and L. rhamnosus NBIMCC 507

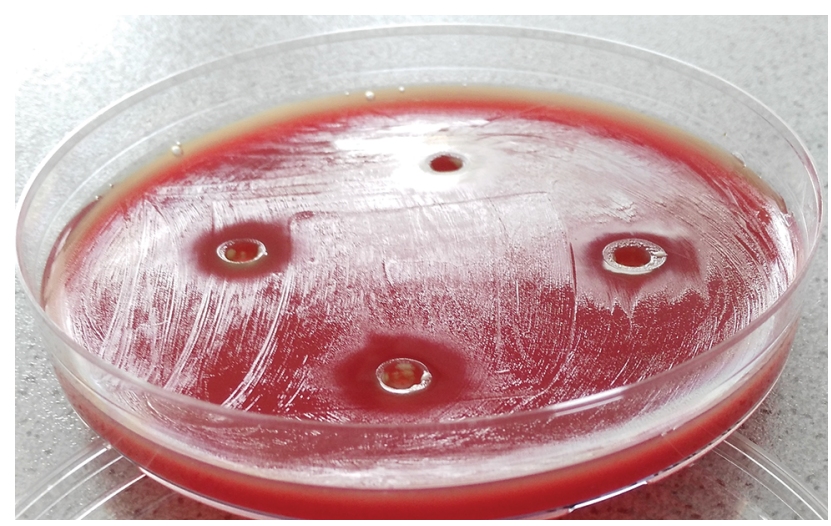

Figure 1. Inhibition of $P$. gingivalis DSM 20709 growth within clear zones around wells loaded with reconstituted freeze-dried milk fermented with S. thermophilus 187/4 (agar well diffusion assay, four parallel wells).

inhibition of the pathogen was only found with the application of freeze-dried preparations, confirming the overall higher activity of reconstituted freeze dried fermented milks compared to "fresh" fermented milk.

In the agar well diffusion assay, milk as control had a negligible effect on $P$. gingivalis (Table 2). However, the effect of milk acidified with lactic acid was apparent with minimal bactericidal zone observed at concentration of lactic acid as low as $0.1 \%$. As positive controls, the two preparations used for mouth hygiene, Elgydium (tooth paste) and Eludril (mouth rinse) gave the maximal antibacterial effect observed in this study - inhibition zone of 7.0 mm (Table 2).

Table 1. Inhibition of P. gingivalis DSM 20709 by selected lactobacilli and S. thermophilus strains

\begin{tabular}{|c|c|c|}
\hline \multirow{2}{*}{ Strain } & \multicolumn{2}{|c|}{ Inhibition zone $(\mathrm{mm})^{*}$} \\
\hline & Fermented milk & Freeze-dried fermented milk ${ }^{\star *}$ \\
\hline L. delbr. ssp. bulgaricus LBB.B1054 & $(2.0)^{\star \star \star \star \star}$ & $2.5+(0.5)^{\star * \star}$ \\
\hline L. delbr. ssp. bulgaricus $\mathrm{C} 3 / 2$ & $(3.0)$ & $1.0+(1.5)$ \\
\hline L. delbr. ssp. bulgaricus $53 / 8$ & $0^{* * * *}$ & ND \\
\hline L. delbr. ssp. bulgaricus LBB.B130 & 0 & ND \\
\hline L. delbr. ssp. bulgaricus LBB.B120 & $(1.0)^{* * * *}$ & ND \\
\hline L. delbr. ssp. bulgaricus 69/6P & 0 & ND \\
\hline L. delbr. ssp. lactis LBB.L1266 & $(0.5)$ & 2.0 \\
\hline L. helveticus LBB.H48/1 & $(2.0)$ & $2.0+(1.0)$ \\
\hline L. helveticus 2096/6 & $(0.5)$ & ND \\
\hline L. rhamnosus I-1/13 & $(1.0)^{\star * * *}$ & 3.0 \\
\hline L. rhamnosus I-4/1 & $0^{\star * * *}$ & 4.0 \\
\hline L. rhamnosus NBIMCC 507 & $0^{* * * *}$ & $2.0+(1.0)$ \\
\hline S. thermophilus $187 / 4$ & $(10.0)$ & $4.0+(0.5)$ \\
\hline S. thermophilus C2 & 0 & $(1.0)$ \\
\hline L. reuteri (commercial preparation) & $(3.0)$ & ND \\
\hline
\end{tabular}

${ }^{\star}$ bactericidal effect (bacteriostatic effect presented in parenthesis), average from two independent trials; ${ }^{\star *}$ freeze-dried preparations reconstituted in water to $10 \%$ dry matter; ${ }^{* * *}$ L. delbr. ssp. bulgaricus LBB.B1054 was thermally inactivated before freeze-drying; ${ }^{* * * *}$ growth of LAB around the well; ND: not determined 
Table 2. Effect of lactic acid and commercial mouth hygiene products on the growth of $P$. gingivalis DSM 20709

\begin{tabular}{ll}
\hline Controls & $\begin{array}{l}\text { Inhibition zone } \\
(\mathbf{m m})^{*}\end{array}$ \\
\hline Milk & $(0.5)$ \\
Milk, 0.1\% lactic acid & 1.0 \\
Milk, 1.0\% lactic acid & 1.5 \\
Milk, 3.0\% lactic acid & 4.0 \\
Milk, 5.0\% lactic acid & 3.0 \\
Milk, 7.0\% lactic acid & 6.0 \\
Elgydium (tooth paste) & 7.0 \\
Eludril (mouth rinse) & 7.0 \\
\hline
\end{tabular}

* bactericidal effect (bacteriostatic effect presented in parenthesis), average from two independent trials

\section{DISCUSSION}

Several studies emphasize the relation between altered oral microflora and the presence of periodontal disease. Van Essche et al. ${ }^{14}$ performed a large scale study to demonstrate the prevalence of bacterial isolates antagonistic to P. gingivalis, Prevotella intermedia, Fusobacterium nucleatum and Aggregatibacter actynomycetemcomitans in samples from healthy individuals compared to patients with periodontitis. Comparing these isolates with seven commercially available probiotic bacteria, the authors found that the effect of the latter was much stronger and that all of the probiotic strains inhibited $P$. gingivalis. Kõll-Klais et al. ${ }^{15}$ found that $P$. gingivalis was inhibited by oral lactobacilli and that in healthy individuals a prevalence of obligatory homofermentative species was observed compared to chronic periodontitis patients. Both authors ${ }^{14,15}$ attribute the effect of lactic acid bacteria on the pathogens mainly to the production of large amounts of organic acids, such as lactic and acetic acid, and especially to the inability of $P$. gingivalis to grow at $\mathrm{pH}$ bellow $6.5 .{ }^{16}$ In terms of dietary nutrition, a comprehensive study of 942 subjects confirmed that consumption of lactic acid foods may have a beneficial effect on periodontal diseases. ${ }^{8}$

In our study, milk acidified with lactic acid clearly and in concentration-dependent manner inhibited the growth of $P$. gingivalis forming clear bactericidal zones around the wells (Table 2). However, although all tested lactobacilli and S. thermophilus strains produced lactic acid to coagulate milk, the presence and extent of pathogen inhibition was strain-specific. This indicated the presence of other metabolites that play an essential role in the inhibition of $P$. gingivalis. One example is the synthesis of hydrogen peroxide that is a function of the activity of specific oxidases in L. delbrueckii strains. ${ }^{17}$ Moreover, in our experiments, reconstituted freeze-dried preparations of milks fermented with lactic acid bacteria showed stronger inhibitory effect than the initial fermented milks. Although with the same lactic acid content, fresh fermented milk cultures generated only zones of bacteriostatic effect on the pathogen, while the corresponding reconstituted freeze-dried preparations formed clear zones of bactericidal effect. This may be attributed to the destruction of a portion of the bacterial cells during lyophilisation and the liberation of intracellular content, including inhibitory substances (Table 1). Alternatively, stress factors may accumulate in lactic acid bacteria in the freezing process that increase the activity of the freeze-dried preparations. Many species of lactic acid bacteria are capable of producing antibacterial peptides such as bacteriocins. ${ }^{18}$ Bacteriocin production has been also described for $L$. delbr. ssp. Bulgaricus..$^{19}$ Interestingly, bacilli were found to produce a cold-shock protein-like bacteriocin. ${ }^{20}$ It may be possible that cold shock and freezing may increase the production and availability of such antibacterial substances in the lactic acid bacteria cultures included in our experiment.

In our study, growth of lactobacilli around the well on Wilkins Chalgren blood agar was observed, especially with $L$. delbr. ssp. bulgaricus and L. rhamnosus strains, but this did not result in significantly larger inhibition zones which may be explained by the sensitivity of $P$. gingivalis only to metabolites already accumulated in fermented milk or reconstituted freeze-dried fermented milk preparations. Also, in the case of L. delbr. ssp. bulgaricus LBB.B1054, where the culture was heat-inactivated prior to lyophilisation, clearly $P$. gingivalis was inhibited by heat-stable metabolites rather than by viable cells. The complexity of the mechanism of inhibition of $P$. gingivalis by lactobacilli is well demonstrated in the study of Samot and Badet ${ }^{10}$ where 52 of a total of 66 autochthonous oral lactobacilli slightly inhibited the growth of this pathogen, but only 7 produced hydrogen peroxide, the inhibiting activity was independent of Proteinase K treatment, and higher activity was observed for facultatively heterofermentative cultures.

Strong inhibition of $P$. gingivalis was also observed for S. thermophilus 187/4. Although in yoghurt, cocci are weaker acid producers, Zhu et al. ${ }^{9}$ found that both $S$. thermophilus and L. delbr. ssp. bulgaricus inhibited the growth of $P$. gingivalis, but only if yogurt bacteria were inoculated first as early colonizers. This suggests that the mechanism of antagonism between $S$. thermophilus and P. gingivalis may be competition for substrate. Another study showed that $S$. thermophilus may reduce oral malodour by inhibition of $P$. gingivalis growth and neutralizing volatile sulfur compounds produced by the pathogen. ${ }^{11}$ Again, in our study, the same effect of activation of the inhibitory effect by freeze-drying was observed with $S$. thermophilus $187 / 4$ with bacteriostatic effect of fermented milk enhanced to bactericidal effect of the lyophilized preparation (Table 1).

Stamatova et al. ${ }^{7}$ tested the inhibitory activity of lactobacilli against five clinical isolates of $P$. gingivalis and determined that $L$. casei ATCC 344 was the most potent culture inhibiting four of the pathogen isolates, followed by L. rhamnosus strain that showed the highest activity against three of the P. gingivalis isolates. Nevertheless, the authors 
observed only "slight inhibition of growth" of $P$. gingivalis by $40 \%$ of the tested lactobacilli and no inhibition of the pathogen by L. delbr. ssp. bulgaricus strains. This discrepancy with our results for L. delbr. ssp. bulgaricus LBB.B1054 and $\mathrm{C} 3 / 2$ can be explained by the difference in the antimicrobial activity test method which in the experiment of Stamatova et al. ${ }^{7}$ was streak line method on Brucella agar, while in our study we used the well-diffusion assay testing directly fermented milk preparations on Wilkins Chalgren blood agar and P. gingivalis DSM 20709 as a test culture. Notably, with the agar-overlay method, Stamatova et al. ${ }^{7}$ have observed inhibitory activity of $L$. delbr. ssp. bulgaricus strains against other oral pathogens such as some species of streptococci and $A$. actynomycetemcomitans.

In vitro selection of potential probiotic lactic acid bacteria should be followed by clinical trials. The results of this study supported the performance of initial trials with freeze-dried preparations of $L$. delbr. ssp. bulgaricus LBB. B1054 and S. thermophilus 187/4 with encouraging results showing favourable change in the species distribution of bacterial species in patients with periodontitis, decrease of $P$. gingivalis counts and improvement of periodontal status after additional intake of the probiotic preparations. ${ }^{21,22}$

\section{CONCLUSIONS}

The agar well diffusion assay showed that $P$. gingivalis DSM 20709 was sensitive to the metabolites produced in fermented milk by several species of lactobacilli (L. delbr. ssp. bulgaricus, L. helveticus, and L. rhamnosus) and S. thermophilus in a strain-specific manner, with $L$. delbr. ssp. bulgaricus and S. thermophilus being the typical microflora of yoghurt. Reconstituted freeze dried fermented milk samples had a stronger inhibitory effect compared to fresh fermented milks which suggests that a better effect may be achieved by application of probiotic preparations in a lyophilized form. Clearly lactic acid, produced by lactic acid bacteria, was among the active metabolites inhibiting the pathogen. The heat-treated preparation of L. delbr. ssp. bulgaricus LBB. B1054 preserved its inhibitory activity emphasizing that it is the metabolites rather than viable cells that were the mediator of the effect of $P$. gingivalis inhibition for this strain.

\section{Acknowledgements}

The study was partially funded by the Medical University of Plovdiv, Plovdiv, Bulgaria, Project SDP 04/17 "Initiation of PhD programs".

\section{REFERENCES}

1. Bostanci N, Belibasakis GN. Porphyromonas gingivalis: an invasive and evasive opportunistic oral pathogen. FEMS Microbiol Lett 2012; 333:1-9.
2. Mysak J, Podzimek S, Sommerova P, et al. Porphyromonas gingivalis: Major periodontopathic pathogen overview. J Immunol Res 2014; 476068.

3. Rafiei M, Kiani F, Sayehmiri F, et al. Study of Porphyromonas gingivalis in periodontal diseases: a systematic review and meta-analysis. Med J Islam Repub Iran 2017; 31:62.

4. Sato K, Takahashi N, Kato T, et al. Aggravation of collagen-induced arthritis by orally administered Porphyromonas gingivalis through modulation of the gut microbiota and gut immune system. Sci Rep 2017; 7(1):6955.

5. Öğrendik M. Periodontal pathogens in the etiology of pancreatic cancer. Gastrointest Tumors 2016; 3:125-7.

6. Singhrao SK, Harding A, Poole S, et al. Porphyromonas gingivalis periodontal infection and its putative links with Alzheimer's disease. Mediators of inflammation 2015; 137357.

7. Stamatova I, Kari K, Meurman J. In vitro evaluation of antimicrobial activity of putative probiotic lactobacilli against oral pathogens. Int $J$ of Probiotics \& Prebiotics 2007; 2:225-32.

8. Shimazaki Y, Shirota T, Uchida K, et al. Intake of dairy products and periodontal disease: the Hisayama study. J Periodontol 2008; 79:131-7.

9. Zhu Y, Xiao L, Shen D, et al. Competition between yogurt probiotics and periodontal pathogens in vitro. Acta Odontol Scand 2010; 68(5):261-8.

10. Samot J, Badet C. Antibacterial activity of probiotic candidates for oral health. Anaerobe 2013; 19:34-8.

11. Lee SH, Baek DH. Effects of Streptococcus thermophilus on volatile sulfur compounds produced by Porphyromonas gingivalis. Arch Oral Biol 2014; 59(11):1205-10.

12. Matsubara VH, Bandara HM, Ishikawa $\mathrm{KH}$, et al. The role of probiotic bacteria in managing periodontal disease: a systematic review. Expert Rev Anti Infect Ther 2016; 14(7):643-55.

13. Soleimani NA, Kermanshahi RK, Yakhchali B, et al. Antagonistic activity of probiotic lactobacilli against Staphylococcus aureus isolated from bovine mastitis. Afr J Microbiol Res 2010; 4(20):2169-73.

14. Van Essche M, Loozen G, Godts C, et al. Bacterial antagonism against periodontopathogens. J Periodontol 2013; 84:801-11.

15. Kõll-Klais P, Mändar R, Leibur E, et al. Oral lactobacilli in chronic periodontitis and periodontal health: species composition and antimicrobial activity. Oral Microbiol Immunol 2005; 20:354-61.

16. Takahashi N, Schachtele CF. Effect of $\mathrm{pH}$ on the growth and proteolytic activity of Porphyromonas gingivalis and Bacteroides intermedius. J Dent Res 1990; 69(6):1266-9.

17. Cornacchione LP, Klein BA, Duncan MJ, et al. Interspecies inhibition of Porphyromonas gingivalis by yogurt-derived Lactobacillus delbrueckii requires active pyruvate oxidase. Appl Environ Microbiol 2019; 85(18):e01271-19.

18. Meade E, Slattery MA, Garvey M. Bacteriocins, potent antimicrobial peptides and the fight against multi drug resistant species: resistance is futile? Antibiotics (Basel) 2020; 9(1):32.

19. Kim H-J, Kim J-H, Son JH, et al. Characterization of bacteriocin produced by Lactobacillus bulgaricus. J Microbiol Biotechnol 2014; 14(3):503-8

20. Huang T, Zhang X, Pan J, et al. Purification and characterization of a novel cold shock protein-like bacteriocin synthesized by Bacillus thuringiensis. Sci Rep 2016; 6:35560.

21. Yaneva B, Dermendzhieva Y, Dobrev I, et al. Antibacterial activity of probiotic strains against periodontal pathogens - pilot clinical examination. Scientific works of the Union of Scientist in Bulgaria - Plo- 
vdiv, series G. Medicine, Pharmacy and Dental Medicine. 2020; vol. XXIV:348-52.

22. Dermendzhieva Y, Yaneva B, Dobrev I, et al. Examination of probiotic application on clinical parameters in periodontitis treatment. Scientific works of the Union of Scientist in Bulgaria - Plovdiv, series G. Medicine, Pharmacy and Dental Medicine. 2020; XXIV:394-8.

\title{
Кандидаты в пробиотики из молочных штаммов Lactobacilli и Streptococcus Thermophiles для борьбы с оральным патогеном Porphyromonas Gingivalis
}

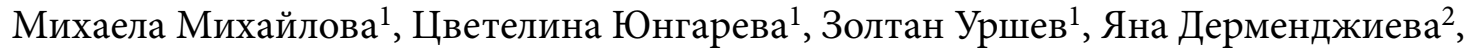 \\ Благовеста Янева ${ }^{2}$, Илиян Добрев ${ }^{3}$ \\ ${ }^{1}$ „Ел Би Булгарикум“ ЕАО, Центр RњD, София, Болгария \\ ${ }^{2}$ Кабедра пародонтологии и заболеваний слизистой оболочки полости рта, Факультет дентальной медицинь, Медицинский университет - \\ Пловдив, Пловдив, Болгария \\ ${ }^{3}$ Кафедра микробиологии, Университет пищевых технологий, Пловдив, Болгария
}

Адрес для корреспонденции: Михаела Михайлова, „Ел Би Булгарикум“ ЕАО, Центр R\&D, ул. „Саборна“ № 9, 1000 София, Болгария; E-mail: michaylova.m@lbbulgaricum.bg

Дата получения: 15 июля $2020 •$ Дата приемки: 21 октября $2020 \bullet$ Дата публикации: 31 октября 2021

Образец цитирования: Michaylova M, Yungareva T, Urshev Z, Dermendzieva Y, Yaneva B, Dobrev I. Probiotic candidates among dairy Lactobacilli and Streptococcus thermophiles strains for control of the oral pathogen Porphyromonas gingivalis. Folia Med (Plovdiv) 2021;63(5):720-5. doi: 10.3897/folmed.63.e56551.

\section{Резюме}

Введение: Грамотрицательная бактерия Porphyromonas gingivalis является основной причиной пародонтита у взрослых. Это также связано с нарушениями сердечно-сосудистой и эндокринной систем, ревматоидным артритом, раной поджелудочной железы и болезнью Альцгеймера.

Молочнокислые бактерии (МКБ), присутствующие в полости рта и принимаемые в качестве пробиотиков, могут сопровождать успешное лечение пародонтита из-за их антагонизма с возбудителем.

Цель: Целью данного исследования было выполнить in vitro оценку антимикробной активности Lactobacillus spp. и Streptococcus thermophilus против P. gingivalis

Материалы и методы: Антимикробный эффект лактобацилл или S. thermophilus из коллекции культур МКБ против P. gingivalis DSM 20709 оценивали с использованием метода диффузии в лунках кровяного агара Уилкинса-Чалгрена. Ингибирование патогенов оценивали путём измерения диаметра чистых участков вокруг лунок с агаром.

Результаты: Применение молока, ферментированного выбранным МКБ, вызывало бактериостатический эффект. Наиболее активной культурой была S. thermophilus 187/4, за ней следовала L. delbr. ssp. bulgaricus (LBB.B1054, C3/2 и LBB.B120), L. helveticus LBB.H48/1 и L. rhamnosus I-1/13. Соответствующие лиофилизированные препараты, восстановленные из сухого молока, оказывали более сильное ингибирующее действие на возбудителя с образованием чистых бактерицидных зон. Эффект молока, подкисленного молочной кислотой, был очевиден с минимальными бактерицидными зонами, наблюдаемыми при концентрациях 0.1\%. Эффективность анализа подтверждена препаратами Elgydium и Eludril.

Заключение: P. gingivalis DSM 20709 был чувствителен к метаболитам, продуцируемым в ферментированном молоке отобранными штаммами L. delbr. ssp. bulgaricus, L. helveticus, L. rhamnosus и S. thermophilus. Лиофилизированное ферментированное молоко, восстановленное из сухого молока, имело более сильный ингибирующий эффект, чем свежие образцы. Молочная кислота, продуцируемая молочнокислыми бактериями, была ключевым компонентом в подавлении патогена.

\section{Ключевые слова}

ингибирование, Lactobacillus, пародонтит, Streptococcus thermophilus 